(C) The Author(s), 2021. Published by Cambridge University Press. This is an Open Access article, distributed under the terms of the Creative Commons Attribution licence (http://creativecommons.org/licenses/by/4.0/), which permits unrestricted re-use, distribution, and reproduction in any medium, provided the original work is properly cited. doi:10.1017/S1474746421000610

\title{
Intra-Crisis Lesson-Drawing in Real-Time: The Pandemic Lessons Available in the UK Media during the First Months of COVID-19
}

\author{
Ian Greener* (D), Martin Powell** and Sophie King-Hill*** \\ *University of Strathclyde, Glasgow, UK. \\ E-mail: ian.greener@strath.ac.uk \\ **University of Birmingham, Birmingham, UK. \\ E-mail: m.powell@bham.ac.uk \\ ***University of Birmingham, Birmingham, UK. \\ E-mail: s.kinghill@bham.ac.uk
}

This article assesses, using a framework derived from lesson-drawing, policy transfer and crisis research, the lessons offered by the media from abroad and from the past in the UK COVID-19 pandemic. The lesson-drawing literature focuses on a series of steps and questions associated with the 'fungibility' of lessons, and the crisis literature, with its constituent elements of threat, uncertainty and between 'routine' and 'non-routine' or 'less routine' crises. The article utilises the LexisNexis Database ${ }^{1}$ in order to provide a content analysis of newspaper coverage of lessons offered, giving analysis in 'real time' of the source of potential lessons (e.g. past pandemics or other nations), and the type of lessons (e.g. copying or instruments). Its analysis highlights the complexity of lesson-drawing in 'real time' in a period of considerable uncertainty, where knowledge is contested, and is subject to change over time.

Keywords: COVID-19, lesson-drawing, media, UK.

\section{Introduction}

This article brings together the literatures on lesson-drawing, policy transfer and intra-crisis literature to consider the health pandemic response lessons available from the UK national newspaper media to the public, and to policymakers, in respect of the first months of the COVID-19 pandemic. It focuses on the supply of lessons offered by the media that seek to provide information of learning from the past (e.g. previous pandemics) or from abroad up to 13/06/2020. It brings together elements from the Dolowitz and Marsh (1996, 2000) framework of policy transfer, considering the type and source of lessons, and the crisis perspective (threat, uncertainty, and urgency in a non-routine and intra-crisis situation). The material is primarily drawn from LexisNexis database of newspapers, and is analysed by Interpretative Content Analysis. We were interested in the news media as this links the neglected connection between media and policy studies of agenda setting. As Wolfe et al. (2013) put it, the central questions that drive agenda-setting in communications and policy studies are: what issues are on the agenda; which are not; when and why. The media are integral to both, yet these traditions do not communicate as much as they could or as 
much as they should. This focus complements lessons from other sources such as politics and science (Powell and King-Hill, 2020; King-Hill, Greener and Powell, 2021). Our study cannot say how the media directly affects policy, but it can throw light on the content of the lessons the media were presenting to policymakers as they attempted to meet the challenges of the pandemic. In broad terms, we seek to answer the question - 'What lessons were available to policy makers from the UK media response to the first wave of the pandemic?'

The article proceeds as follows. First it derives its analytical framework, then its data source. It then moves onto its results, first in the form of an overall summary, then exploring key headings - lessons from previous pandemics, the emergence of the virus and China's response, lessons from Italy, and lessons from Germany. It then considers the lessons offered by the media coverage comparatively, before concluding by suggesting that UK policymakers may have learned the 'wrong' lessons in their pandemic response.

\section{The UK context}

In terms of the COVID-19 crisis and the success of the policies that were implemented, the UK does not appear to have fared greatly. The UK is third in the world for deaths per capita with 1,749 deaths per million (as of $15^{\text {th }}$ February 2021) which totals over 116,945 deaths (JHU, 2020). This is despite numerous policies being introduced in the form of nonpharmaceutical interventions (NPIs). The influence for these NPIs come from political, economic and scientific models and were grounded within the epidemiological models offered by Imperial College (Pawson, 2020). These have then fed into the governments Scientific Advisory Group for Emergencies (SAGE) and its sub-committees (the New and Emerging Respiratory Virus Threats Advisory Group - NERVTAG, the Scientific Pandemic Influenza Group on Modelling -SPI-M, and behavioural public policy - SPI-B) (Cairney, 2020; HMG, 2020). The NPIs that have been introduced range in complexity and combine to achieve differing results, but it is fair to say that the UK government response, when compared against other countries, was late (Nickson et al., 2020) and the interventions introduced were often complex, confusing and lacking a clear strategy.

When exploring the UK approaches to COVID-19, comparisons can be made with abroad and the past. The government Action Plan (HMG, 2020) sets out the UK was well prepared for a pandemic as it had responded to diseases well in the recent past, being prepared for an influenza outbreak, with these plans appearing to 'frame' the UK government COVID-19 response, However, Asian countries, in treating COVID-19 in a similar way to SARS and MERS, both of which they had experienced, seem to have responded more appropriately.

The COVID-19 pandemic response offers policymakers the most serious challenge in a generation. What lessons were publicly available from the past, or as they emerged, from other countries? To explore this question, the article first considers what research on lesson-drawing and policy transfer offers in terms of a means of constructing a framework to answer that question.

\section{Lesson drawing and policy transfer in space and time}

Many major theories and frameworks in the public policy literature, including policy transfer, draw on key elements such as who learns, what they learn, and the effects of 
learning on subsequent policies. Later reviews broadly set out similar issues, and stress the importance of Rose on lesson-drawing and Dolowitz and Marsh on policy transfer (e.g. Grin and Loeber, 2007; Heikkila and Gerlak, 2013; Vagionaki and Trein, 2020).

Dolowitz and Marsh (1996: 344) stated that 'policy transfer, emulation and lesson drawing all refer to a process in which knowledge about policies, administrative arrangements, institutions etc. in one time and/or place is used in the development of policies, administrative arrangements and institutions in another time and/or place'. Although this 'classic definition' (Hadjiisky et al., 2017: 1) treats the different terms as synonymous, subsequent writers have pointed to different 'songlines' or 'pathways' (Hadjiisky et al., 2017) or 'conversations' within disciplinary perspectives (Baker and Walker, 2019).

Both 'lesson drawing' (Rose, 1991, 1993) and policy transfer (Dolowitz and Marsh, $1996,2000)$ stress that lessons can be drawn from the past and from overseas. Rose (1991: 6) writes that 'everyone concerned with public policy unconsciously draws lessons across time and space.' As policymakers do not have time or capacity to search everywhere, they first follow the line of least resistance and start searching near at hand, or at the most proximate source in a time-space continuum. However, when a problem is unprecedented, the past cannot always offer a solution. Policymakers must then search further afield, which may include searching across space. Rose differentiates between perfect or 'total fungibility' (programmes that operate logically in a theoretical model are expected to be applicable anywhere and everywhere) and 'total blockage' (where theories grounded in history, institutions and culture make it impossible to transfer a programme from one country to another, one city to another, or even to apply past experience to the present). He stresses the probability or improbability of transfer, posing the prospective question: can a programme now operating in country $X$ be put into effect in country $Y$ in future?

Dolowitz and Marsh (1996, 2000) constructed a framework for considering how policy makers engaging in 'learning' of the 'lessons' that are available to them, first suggesting a framework based around a series of questions: Who transfers policy? Why engage in policy transfer? What is transferred? Are there different degrees of transfer? From where are lessons drawn? What factors constrain policy transfer? In the further development of their framework they added an additional question in which a judgement about whether the process was judged to be a policy 'success' or 'failure' was made (Dolowitz and Marsh, 2000).

Although the terms 'lesson-drawing' and policy transfer are often used synonymously, with Rose using the former, Dolowitz and Marsh appear to present lesson-drawing as an early stage of policy transfer (Dolowitz and Marsh, 2000, p.10) in which policymakers search for alternatives from elsewhere. This distinction is helpful, and will be incorporated into the discussion below.

\section{Crisis}

Much of the research on lesson-drawing and policy transfer literatures is based, even though policymakers may not have realised it, on 'normal' times. However, lessondrawing in a crisis might be a very different process (e.g. Moynihan, 2008, 2009). Many commentators draw on the definition of a crisis by Rosenthal et al. (1989: 10), with its constituent elements of threat, uncertainty, and urgency (e.g. Moynihan, 2008, 2009; Boin et al., 2018). According to Boin et al. (2018), crises create impossible conditions for those 
who seek to manage a response operation, forcing them to make urgent decisions while essential information about causes and consequences remains unavailable, unreliable or incomplete.

It is also possible to differentiate between period across crises, and within a crisis, which can be termed 'inter-crisis' and 'intra-crisis' management (Moynihan, 2009). How policy makers lesson-draw and navigate in times of crisis is not well understood (e.g. Boin et al., 2018), and its difficulty may also be greater (Moynihan, 2008, 2009). Brändström et al. (2004) consider a range of cases where decision-makers attempted to draw on lessons from the past in managing a current crisis, differentiating again between what policymakers do 'in' crises (through the use of historical comparisons or analogies during crisis decision-making) and 'from' crises (which is the extent to which crises provide opportunities for policy-oriented learning).

Moynihan (2008, 2009) also helpfully differentiates between 'routine' and 'nonroutine' or 'less routine' crises. During routine crises, standard procedures that seem to work well in one setting can generally be applied to another context, such as might be the case between forest fires and earthquakes. However, where policymakers find themselves in a less familiar crisis this makes non-routine tasks much more di区cult to manage. It is clear, however, that COVID does not represent a routine crisis, and so we would expect to look for lessons both from aboard, during the current pandemic, and from previous ones.

\section{Framework}

The frameworks present in the lesson-drawing (Rose, 1991, 1993) and policy transfer perspectives (Dolowitz and Marsh, 1996, 2000) have at their core an emphasis on where lessons are drawn from (the past or other nations), the content of what is transferred, and whether lessons are positive or negative. We incorporate each of these dimensions into our analysis, but also consider the additional problems of intra-crisis policy transfer with its constituent elements of threat, uncertainty, and urgency (e.g. Moynihan, 2008, 2009; Boin et al., 2018). In such circumstances, lessons must be learnt quickly in real time and based on evidence with large confidence limits and subject to change

\section{Empirical study}

Our study focuses on the UK, which is generally regarded as a poor performer, with high infection and mortality rates, and significant economic disruption (e.g. rise in unemployment and fall in GDP per capita), despite high expenditure by government. It is generally considered that the UK failed to secure its borders, locked down late, and developed a problematic 'Test, Trace and Isolate' system. In the early period, the main problem seemed to be the lack of available tests, but throughout the period the failure to reach sufficient numbers and their contacts, slow turnaround, and failure to ensure a high number of those required to isolate have been persistent problems (see e.g. Cairney, 2020; Nickson et al., 2020).

News articles give us a clear sense of both what factual information was available and known at different time periods, as well as which problems were regarded as being sufficiently significant to be reported, and which elements of those problems were most debated. In relation to the COVID pandemic, the data makes it possible to see a clear chronology of when the virus began to be taken seriously, and of its reported subsequent spread across different nations. 
To explore where and when the lessons from COVID appeared in news sources, we utilised the Nexis database, which contains published news articles from both paper and online sources from a range of national and international sources. Because COVID has appeared so widely, and so frequently, since the first news articles noting is appearance appeared in early 2020, it was necessary to restrict the search terms we used, as well as the sources we considered. Because we wanted news articles which were both concerned with COVID and which offered lessons from both the past and from other countries as their primary content, we constructed a search that looked for these elements in the headline and leading paragraphs. We then put in place exclusion terms to remove articles that were not relevant to our research goals, as a result removing discussions about detailed classroom practices in schools, and the impact of COVID on investors.

We considered UK national newspapers only as we were interested in how the UK did not appear to engage in substantial policy from the experience of other nations which the virus reached first. Restricting to national newspapers meant that the articles contained within them tended to be concerned with a more general level of politics and discussion than local newspapers tend to.

The final search terms in Nexis were "headline (COVID OR coronavirus) AND headline (lesson* OR learn*) AND NOT ("schools" OR "education" OR "classroom" OR "PE" OR "investor")', restricted to UK national newspapers only. This combination generated 377 articles at the time of search on 13/06/2020. This period therefore deals with the first wave pandemic response in the UK, during which it went from observing the virus from the other side of the world, to having to put in place a societal level response to it. This period also captures the period of the initial crisis response. The main inclusion criterion was that articles had to provide, in the view of all the authors of the article (assessing independently) a clear lesson from either another nation or from the past, and resulted in a final list of fifty-four articles.

This study uses Interpretive Content Analysis (ICA) (Drisko and Maschi, 2016). It uses a deductive approach that deals with both manifest and latent content. A deductive approach is useful if the general aim is to test a previous theory, and keywords are derived from the interest of researchers or review of literature. Manifest ICA involves analysing for the appearance of a particular word or content, while latent ICA refers to the process of interpretation of content, or discovering underlying meanings of the words or the content. In addition to key words, it drew on connotative codes, which are based not on explicit words but on the overall or symbolic meaning of phrases or passages. All three authors read and coded the articles independently, and then agreed the final codes through a process of consensus and deliberation.

\section{Results}

The fifty-four articles that resulted from the sampling process outlined above tended to appear in the 'broadsheet' rather than the 'tabloid' press and are included in appendix one, along with the 'direction' of the lesson they offer (positive/negative). There were fourteen articles in the 'Guardian' (and one in the 'Observer'), eleven in 'The Independent', twelve in the 'Daily Express', nine in the 'Daily Telegraph', three in the 'Times' or 'Sunday Times', two in the 'Daily Mail' and two in the 'Daily Mirror'.

In terms of chronology, the first article appeared on $23^{\text {rd }}$ January 2020. There were two articles in January, four in February, nineteen in March, seventeen in April, ten in May 
and two in early June up to our search date. For the source of lessons, thirty-five articles focused on other nations; seven focused on the past; and twelve explored other nations in the past (mostly SARS). The most featured 'nations' were China (fifteen), Germany (nine), Italy (nine), Korea (six), Hong Kong (3), Singapore (three), Taiwan (three), and USA (two), and Canada, 'East Asian nations', Ecuador, India, Iran, Liberia, New Zealand, South Africa, Spain and 'West Africa' once each. The most featured historical point of comparison was SARS (eight), 'Spanish flu' (five), Ebola (two), 'plagues', the 'Great Plague' HIV, MERS and smallpox. There were many different elements of content of the lessons, but they can be broadly grouped in openness, transparency and free speech (China); speed and strength of 'lockdown' (China), test, trace and isolate (Germany, Korea), preparedness and infrastructure (mainly East Asian nations after SARS and MERS, but also Africa after Ebola), and lack of hospital beds (especially ITU beds, and lack of PPE) (Italy). Our coding agreed that the East Asian nations and Germany were broadly seen as providing positive lessons, while Italy was largely associated with negative lessons (health system, and 'open for business'). China was regarded as providing both negative (initial denial, cover-up and slow response) and positive (lockdown) lessons. The past seemed to provide more mixed messages. East Asian nations were seen as being more prepared for COVID-19 as they learned lessons from SARS or MERS. The response to 'Spanish flu' was more mixed: some cities responded with effective lockdowns, while others attempted to 'carry on' or emerged from lockdown too soon, leading to a more deadly second wave. A summary of the articles in chronological order is given in Appendix 1.

We now turn to examine the four most-mentioned higher level topics or themes within this data, with citations of specific data. Within this section, individual articles carrying numbers are cited using the Vancouver method (to differentiate them from the academic sources), and the cited articles are listed in Appendix 2 - which is available online (Supplementary Materials).

\section{Lessons from previous pandemics}

As noted above, in the early days of uncertainty about a new virus and with significant lagtime before knowing whether interventions such as lockdowns worked, the main focus was on lesson-drawing from previous pandemics, with the earliest articles comparing China's response to SARS (1-5) and COVID - which were also picked up in March $(6,7)$. However, what was perhaps less unexpected is the extent to which stories appear throughout the period under study, even as news about COVID becomes more widely-known.

In late January and early February links to Ebola $(8,9)$ and Zika (4) were made, with the need for the world to share in knowledge around 'infrastructure', 'virus containment', surveillance and tracking' that needed to be learned, and for the government to issue 'regular and honest updates' which it had struggled to do after early outbreaks in Worthing and Brighton.

In March, Hague (10) drew three lessons - world interdependence; the problems that authoritarian political systems had in managing crises 'honestly, openly and successfully' (with links to Iran and China being made); the consumption and trafficking of the world's endangered wildlife. These last two themes linked to the response from China especially.

By March, lessons from Italy were being drawn from its past (11), emphasising the need for quarantine, but with concerns about xenophobia emerging as a result. The general 
lesson in other pieces was one about 'containment', which was linked in the modern age with the need for strong public health information to be given out: about the danger of 'fake news' especially via social media (12).

In March, comparisons with the 1918 Flu pandemic were made which offered lessons around the need to cover mouths, wear a mask, avoid public transport and stay at home, as well as the danger of excess mortality for people aged sixty-five and over, the need to separate the sick from the well, and for regular hygiene practices and quarantine protocols $(13,14)$. In April a further piece with the same comparison stressed a greater investment in vaccine research, and to learn from the epidemiology from an interdisciplinary perspective, and of the dangers of breakdowns of trust in authority leading to societal breakdown (15). By the end of April a final piece presented US lessons from 1918 in terms of the need for a ban on public gatherings and compulsory face masks, social distancing, but dangers of 'crisis fatigue' and a second wave (16). Finally, in May, a piece stressed 1918 as a warning of avoiding mass deaths and 'survival of the fittest' only (17).

\section{The emergence of the virus and China's response}

Initial coverage of China was hostile because of allegations of a 'cover-up' and lack of 'openness', but with some recognition of its swift response in terms of sequencing the DNA of the virus. The early stories (January and February) are a mix of suspicion with occasional recognition of it acting differently from its response to SARS $(1-3,18)$.

By March China's 'model' was being presented to the world as being one it should follow $(7,19,20)$, with Singapore, Japan and South Korea presented as examples as having done so, but with warnings that countries not engaging in 'targeted measures to improve quarantine and treatment' and 'communication and cooperation' were experiencing 'drastically worsening situations'(21). The EU was presented in this view as having acted too slowly and not treated the virus with sufficient seriousness. However, the increased tensions with the USA also appeared with President Trump referring to COVID as the 'Chinese virus'(21).

By April things were becoming more universally negative, with claims that China has been slow to disclose the scale of the 'disaster' that had happened(22). This criticism then resurfaces in June with claims from recordings at the WHO showing China had been 'slow to share early critical information' about COVID - with China resisting sharing genome sequence for more than a week - and then further stalled for another two weeks in sharing detailed information about data and cases 'at a time when the outbreak might have been dramatically slowed'(23).

By June, China felt the need to defend its handling of the pandemic, accusing critics had gone 'all out to smear and slander China' and were 'spreading a political virus'(24).

\section{Lessons from Italy - a developed nation '2 weeks ahead'}

Italy was the first European country to experience a widespread COVID pandemic, and so had the potential to offer other countries lessons in its handling. On $8^{\text {th }}$ March, Italy's policy was being discussed based around tracking, quarantine and hand-washing, but with concerns about economic consequences about limiting movement being expressed under such an 'experiment' (25). On $12^{\text {th }}$ March, the devastation in Italy was becoming clear with the country being compared to a 'warzone' and lessons about 'serious mistakes 
in sending contradictory or irresponsible messages to the Italian population' (12). Finally, there were concerns that xenophobia to Italians might appear in the same way as Italians had begun to be xenophobic to Chinese people (12).

On $20^{\text {th }}$ March there were lessons about continuing contagion despite the lockdown because of a lack of compliance with it, being based around a lack of clarity over the rules. Some 40,000 citizens had been charged with breaking quarantine rules, and non-essential businesses were being closed to 'drill home the severity of the virus even more'(26).

In the last days of March Italy was reported as being 'overwhelmed' due to the virus being in circulation before the authorities were aware of it (27). Lessons about continued use of public transport ('biological bombs'(28)) were highlighted and of not moving to lockdown quickly enough. Hospitals being especially deadly places and sources of new infections, had patients been kept at home the pandemic would have spread more slowly. There was a lack of data from inadequate testing, and clear messages being sent that the UK needed to learn urgently from that. Britain had a 'duty not to repeat Italy's errors'. A viral outbreak in Italy was linked to a Champions League game between Atalanta and Valencia with a reporter being 'patient zero' after travelling home, giving a lesson about the dangers of mass gatherings $(27,29)$.

In May, Vo became a site of potential policy transfer learning, with the village being reported as managing to eradicate the virus through isolation and testing and tracing and social distancing. The strategy was explained in great detail (30), with the Mayor closing down bars quickly, getting local people tested, quarantining doctors and getting new clinical help. The Governor, who was familiar with infectious disease transmission, then carried out extensive testing, tracing, and found asymptomatic cases. Vo then engaged in mass swab testing and further isolations, and repeated its testing again before becoming virus-free. However, even then there was a need for continual vigilance because of the danger of one person with the virus entering the community.

\section{The road not travelled - Germany}

Germany's approach to COVID was presented as offering a model from which the UK could learn a great deal. These lessons are especially important because Germany appeared to interpret the events in China and Italy very differently the UK. Germany does not appear in coverage until March, where it is reporting as closing its borders with France, Austria and Switzerland, leading to concerns about the movement of medical supplies, and of the threat to the EU as a result.

By April, Germany is being reported as a success story. On $1^{\text {st }}$ April questions were asked in a range of newspapers about why Germany was able to put in place a significant testing programme which the UK lacked (31). On $2^{\text {nd }}$ April the need for 'test, test, test' emphasised by the WHO was seen as being instrumental to the success of South Korea and Germany, but absent from the UK's strategy. Germany was reported as having shipped 1.4 M tests by the end of February but with the UK far behind. It was suggested that Germany's sixteen federal states, all with their own delegated responsibilities for healthcare, offered a lesson to the UK as public health was devolved in the UK, but only in terms of Treasury cuts to councils. The lesson was perhaps about 'the benefits of a social market economy with strong decentralising and socially cohesive values' (32).

UK government figures have been conspicuous in accepting Germany's better response. On $7^{\text {th }}$ April Chief Medical Officer, Chris Whitty was quoted as saying 'We all 
know Germany got ahead in terms of its ability to do testing for the virus and there's a lot to learn from that. We have been trying to learn the lessons from that' (33-35). On $12^{\text {th }}$ April a member of the government's advisory body SAGE, Sir Jeremy Farrar, praised the Germany's 'remarkable' testing capacity which had kept both hospitalisations and deaths low, as well as offering lessons around tracing and isolation from which the UK could learn (36).

Germany's success was also noted by international figures. On $13^{\text {th }}$ April Dr. Nabarro of the WHO stressed the importance of isolation when symptoms were discovered and contact tracing as key lessons from Germany where these had become a 'habit' (37). On $21^{\text {st }}$ May, Germany was highlighted as one of the countries (including South Korea, Hong Kong, NZ, Canada) who have fared better than UK because of testing and isolation. Since late January the German Robert Koch Institute put in place testing as 'a basic epidemiological tool necessary for the virus's containment'. The system was initially hampered by a lack of staff, but hundreds of containment staff were trained and a robust system put into operation (38).

\section{Discussion}

We have examined lessons from the past and from other nations offered by the UK news media up to 13/06/2020, which provides a 'real time' commentary for the public, but also forms a key part of the context within which policy makers have to respond to the crisis. First, in terms of 'breadth' (Appendix 1) we found that more articles appeared in the 'broadsheet' rather than the 'tabloid' press. After the first article in late January, most articles appeared in the period of the peak of the virus in the UK in March and April. While the earliest articles focused on the past, over time more articles explored nations from other nations. The most featured historical point of comparison was SARS. The most featured nations were China, Germany, and Italy (below). However, it is interesting to point to 'the dog that did not bark' in that there was only one story on a nation such as New Zealand, which has been highly praised for its COVID-19 strategy, and no articles on nations such as Japan, Greece, Jamaica and some East European nations such as Georgia, which at the time of writing had recorded relatively low death rates. There were many different elements of content of the lessons, but they can be broadly grouped in openness, transparency and free speech (China); speed and strength of 'lockdown' (China), test, trace and isolate (Germany, Korea), preparedness and infrastructure (mainly East Asian nations after SARS and MERS), and lack of hospital beds (especially ITU beds, and lack of PPE) (Italy).

We then examined lessons from the past and from the three most mentioned nations in more depth. As noted above, in the absence of a vaccine or effective therapies, previous pandemics stressed the importance of non-pharmaceutical interventions (NPIs) such as quarantines, lockdowns, and hygiene measures such as face covering. Articles pointed to both positive and negative lessons from China. Germany was generally seen as a positive lessons, especially in its large capacity for testing. However, Italy was broadly seen as a negative lesson, in not containing the early spread of the virus (e.g. allowing football matches to go ahead), in its mixed messaging between protecting its population and protecting its economy ('open for business'), and in its hospital capacity being overwhelmed. However, there were some positive lessons such as local initiatives in places such as Vo.

Many lessons have been offered, but the extent to which they could be straightforwardly transferred to the UK less clear, as lessons from overseas are often presented in a way that seems to assume perfect fungibility (Rose, 1991) and this will be especially true during 
an intra-crisis period, with its elements of threat, uncertainty and urgency. Even so, in Maor's (2018) terms, the UK government appears to have consistently engaged in policy 'underreaction', with the Prime Minister underplaying the risks associated with the virus until he was forced to act in March 2020, and then repeating the pattern later in the year (Fletcher, 2021). While accepting it is probably easier to transfer particular lessons from particular nations, the UK appears to have moved slowly, underestimating risks and overestimating the costs of rapid action. The 'hard' lockdown had been a key lesson from China, but one that nations may have been initially unwilling to transfer because it is different polity and culture (with China using armed police to impose the lockdown). However, as the situated unfolded in Italy it surely became clear that a similar situation would arrive in the UK. Some lessons can be transferred relatively straightforwardly. Similarly, as was seen in Europe, closing borders can be imposed very quickly - but even by February 2021, and with new variants of the virus appearing at home and overseas, the UK still had not systematically done this. Finally, the delay in the introduction of track-and-trace in the UK was perhaps compromised by not being willing (or able) to trace people's movement through measures such as ATM withdrawals as in Korea, but, the system that was introduced appeared plagued by technical problems and non-compliance (38).

Brändström et al. (2004) differentiate learning in crises (the use of historical analogies during crisis decision-making) and learning from crises (the extent to which crises provide opportunities for policy-oriented learning). It appears the extent of the threat from COVID only really started to be appreciated when the crisis appeared to move from seemingly remote China to Italy, as previous Coronaviruses such as SARS and MERS had most affected Asian nations. Urgency required rapid response, as in nations such as New Zealand and Taiwan, but this lesson appeared not to be learned in the UK. Finally, there was a high degree of uncertainty, clearly illustrated by the range of assumptions used and the huge confidence intervals placed on the mathematical models of the virus. However, perhaps more stress should have been placed on the situation developing in Italy rather than mathematical models. As the founder of the NHS, Aneurin Bevan, put it: why gaze in the crystal ball when you can read the bloody book [or newspaper article]?

\section{Conclusions}

While acknowledging it is difficult to locate fungible lessons from the past and from abroad in crisis situations, to understand the UK's response to COVID, in terms of both the government and the media, we need to take the issue of fungibility seriously in terms of both its institutions, but also in terms of the ideas which are taken for granted by its government in 2020 . We can perhaps see this most clearly by comparing the UK response to that of Germany, expressed through the media articles above.

The media's lessons about Germany appears to be around the importance of its chemistry-based infrastructure in quickly developing widespread testing, and the efficacy of its federal system are contrasted with the UK's centralised government and health service which was unable to respond as effectively. However, other politically federal states (most notably the USA) have not responded effectively to COVID, and the UK's public health system was one which was meant to be delegated to the local authority level. There are examples of UK public health offices (as in Ceredigion) acting in a similar way to those at ' $\mathrm{Vo}_{\mathrm{O}}$ ' by taking charge of testing, tracing and quarantine. However, these seem few and far between, and this is perhaps a sign that, although public health has been 
delegated to local authorities, budget cuts since 2010 have severely limited their capacity to respond to a challenge of the scale of COVID.

It may also be that the UK interpreted what was happening in Italy as requiring an NHS rather than a more general public health response. The UK quickly set up 'Nightingale' hospitals, transferring this approach as a lesson from Italy for fear that intensive care systems might be over-run. This was an understandable response, but led to some perverse outcomes.

First, it meant that insufficient attention was given in March and April to track, trace and quarantine, while Germany's system was coming fully in place. Second, although COVID was interpreted as a hospital-based challenge, this did not lead to sufficient supplies of PPE and a robust testing regime being put in place for NHS workers, let alone workers in care homes. Third, whereas Germany was closing its borders in March, the UK kept them largely open. The UK's view of itself as a travel hub and open economy may have been important here, but this decision, not fully reversed until months later, goes directly against the lessons from previous pandemics around the need to prevent the appearance of new cases. Fourth, interpreting COVID as a challenge to the NHS meant that large numbers of people were discharged from hospitals into care homes to create hospital capacity, but led to COVID infections being spread outside of hospital settings to care homes and care workers.

The evidence above suggests that the UK did not learn available lessons in terms of pandemic response with sufficient seriousness, sufficiently quickly, having regarded reports from China with suspicion, and then treating it as an NHS hospital problem rather than a wider public health one, and reinforcing a range of structural weaknesses based on ten years of reduced funding for social care within an uncoordinated public health network. The community of advice from which the government appeared to draw, including its 'SAGE' committee, seemed to lack public health expertise, putting a premium on epidemiological modelling based on very little data (Cairney, 2020) - even as public health experts were presenting very different interpretations of events in the media (for example, 17); these public health experts appeared locked outside of the policy community, lacking agency as a result (Baker and Walker, 2019, chapter one).

Germany may too have been suspicious of China, but responded quickly to the challenge of COVID, making use of its existing chemistry-based infrastructure in a coordinated way, closing its borders, and filling gaps around tracing through a proactive response to recruiting and training. Germany appears to have reaped the benefits of its federal system and the local accountability it brings to health care, while at the same time putting in place a national coordinated response to testing. The crucial point is that the lessons learned in Germany and the UK from China and Italy put them on policy trajectories which emphasised the strengths (Germany) and weaknesses (the UK) of the wider health and political systems in each country.

\section{Supplementary material}

To view supplementary material for this article, please visit https://doi.org/10.1017/ S1474746421000610.

\section{Note}

1 At the time of writing available at lexisnexis.com. 


\section{References}

Baker, T. and Walker, C. (2019) 'Introduction: the centrality of arenas, agents and actions', in T. Baker and C. Walker (eds.), Public Policy Circulation, Cheltenham, UK: Edward Elgar, 2-24.

Boin, A., 't Hart, P. and Kuipers, S. (2018) 'The crisis approach', in H. Rodríguez, E. Quarantelli and R. Dynes (eds.), Handbook of Disaster Research, Cham, Switzerland: Springer, 23-38.

Brändström, A., Bynander, F. and 't Hart, P. (2004) 'Governing by looking back: historical analogies and crisis management', Public Administration, 82, 1, 191-210.

Cairney, P. (2020) 'The UK government's COVID-19 policy: assessing evidence-informed policy analysis in real time', British Politics, 16, 90-116.

Dolowitz, D. and Marsh, D. (1996) 'Who learns what from whom', Political Studies, 44, 343-57.

Dolowitz, D. and Marsh, D. (2000) 'Learning from abroad: the role of policy transfer in contemporary policy making', Governance, 13, 1, 5-24.

Drisko, J. and Maschi, T. (2016) Content Analysis, Oxford: Oxford University Press.

Fletcher, M. (2021) 'Boris Johnson's dithering over COVID-19 has left the UK fatally exposed - again', New Statesman, 04 January.

Grin, J. and Loeber, A. (2007) 'Theories of policy learning: agency, structure, and change', in F. Fischer, G. Miller and M. Sidney (eds.), Handbook of Public Policy Analysis: Theory, Politics, and Methods, Boca Raton, FI: CRC Press, 201-19.

Hadjiisky, M., Pal, L. and Walker, C. (2017) 'Introduction: traversing the terrain of policy transfer: theory, methods and overview', in M. Hadjiisky, L. Pal, and C. Walker (eds.), Public Policy Transfer MicroDynamics and Macro-Effects, Cheltenham: Edward Elgar, 1-26.

Heikkila, T. and Gerlak, A. (2013) 'Building a conceptual approach to collective learning: lessons for public policy scholars', Policy Studies Journal, 41, 4, 484-512.

Her Majesty's Government (HMG) (2020) Coronavirus Action Plan, 20 March, London: TSO.

Johns Hopkins University (JHU) (2020) COVID-19 Dashboard, https://coronavirus.jhu.edu/map.html [accessed 15.02.2021].

King-Hill, S., Greener, I. and Powell, M. (2021) 'Lesson-drawing for the UK Government during the COVID19 pandemic: a comparison on political, scientific and media lenses', in M. Pomati, A. Jolly and J. Rees (eds.), Social Policy Review 33: Analysis and Debate in Social Policy, 2021, Bristol: Policy Press, 49-74.

Maor, M. (2018) 'Rhetoric and doctrines of policy over- and underreactions in times of crisis', Policy and Politics, 46, 1, 47-63.

Moynihan, D. (2008) Learning under uncertainty: networks in crisis management', Public Administration Review, 68, 2, 350-61.

Moynihan, D. (2009) 'From intercrisis to intracrisis learning', Journal of Contingencies and Crisis Management, 17, 3, 189-98.

Nickson, S., Thomas, A. and Mullens-Burgess, E. (2020) Decision Making in a Crisis: First Responses to the Coronavirus Pandemic, London: Institute for Government.

Pawson, R. (2020) 'The coronavirus response: boxed in by models', Evaluation, 27, 2, 149-67.

Powell, M. and King-Hill, S. (2020) 'Intra-crisis learning and prospective policy transfer in the COVID-19 pandemic', International Journal of Sociology and Social Policy, 40, 9/10, 877-92.

Rose, R. (1991) 'What is lesson-drawing?', Journal of Public Policy, 11, 1, 3-30.

Rose, R. (1993) Lesson-Drawing in Public Policy. A Guide to Learning Across Time and Space, Chatham, NJ: Chatham House Publishers.

Rosenthal, U., Charles, M. T. and 't Hart, P. (eds.) (1989) Coping with Crises: The Management of Disasters, Riots and Terrorism, Springfield, IL: Charles C. Thomas Publishers.

Vagionaki, T. and Trein, P. (2020) 'Learning in political analysis', Political Studies Review, 18, 2, 304-19.

Wolfe, M., Jones, B. and Baumgartner, F. (2013) A failure to communicate: agenda setting in media and policy studies', Political Communication, 30, 2, 175-92. 